\title{
Sir John Floyer's A Treatise of the Asthma (1698)
}

\author{
ALEX SAKULA \\ Formerly consultant physician, Redhill General Hospital, Surrey
}

"I have assign' $d$ the immediate Cause of the Asthma, to the Straitness, Compression, or Constriction of the Bronchia ..."

SIR JOHN FLOYER in the dedication to A Treatise of the Asthma, 1698

The 250th anniversary of the death of Sir John Floyer has prompted a re-examination of the life and work of this remarkable English physician, who is remembered chiefly for his invention of the pulse watch, which provided the first exact method for counting the pulse. Floyer also, however, made a special study of asthma, a condition from which he himself suffered; his $A$ Treatise of the Asthma, published in 1698, was the first major English monograph on the subject and it proved to be an important milestone in the development of our understanding of this disease.

\section{Life of Sir John Floyer (1649-1734)}

Sir John Floyer was born at Hints Hall, Staffordshire, in 1649, the year of the execution of Charles I. His father, Richard Floyer, of Devon stock dating back to Saxon times, was Lord of the Manor of Hints; his mother was Elizabeth Babington. John, the third son, was required to choose a profession and in 1664 he entered Queen's College, Oxford, where he graduated BA in 1668; and then, as John Aubrey puts it, "he entered on the physick line," qualifying MD in $1680^{1}$ (fig 1).

He then settled in Lichfield, prospered as a physician, and became an important member of the community. He was knighted by James II in 1686, but this was probably for political services rather than for medical achievement, in which he had not yet distinguished himself. He married Sarah, daughter of Sir Henry Archbold, and two sons, John and Archbold, were born to them. ${ }^{2}$

Floyer's life spanned the period during which mediaeval conservatism in medicine gradually gave way to a more enlightened experimental approach.

Address for reprint requests: Pilgrims Corner, Pilgrims Way, Reigate, Surrey.

Accepted 19 December 1983

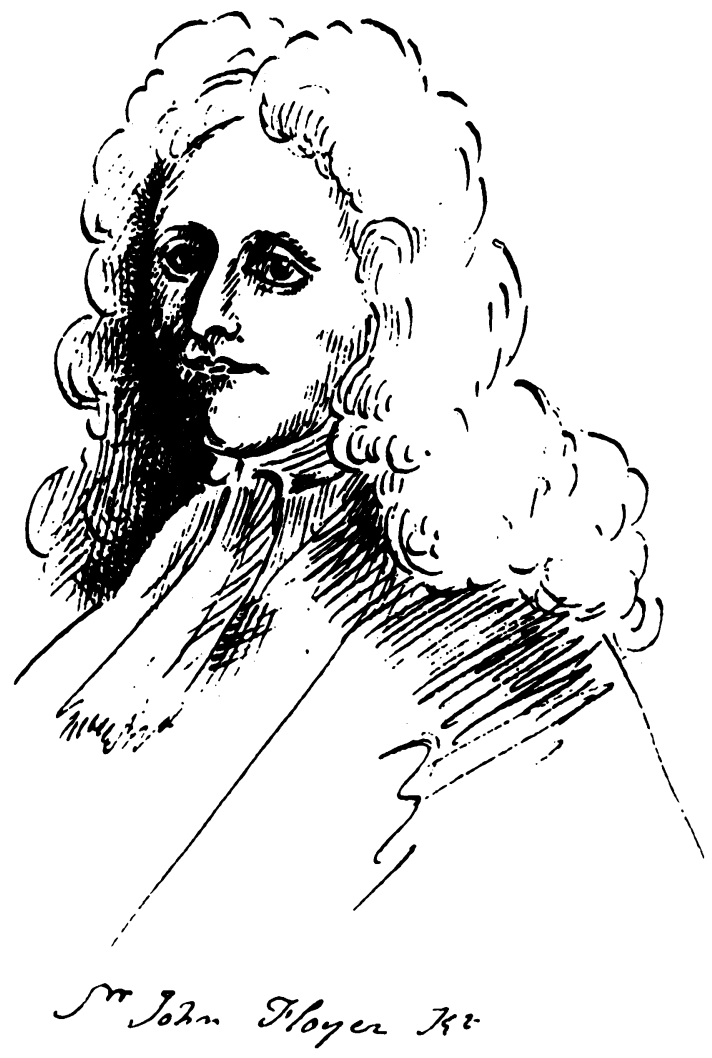

Fig 1 Sir John Floyer, the only known portrait, from a volume in the Bodleian Library, Oxford. (By courtesy of the Wellcome Institute Library, London.)

His clinical practice embraced elements of both attitudes. For example, he subscribed to the ancient galenic teaching and believed that the taste and smell of botanical drugs should correspond with the taste and smell of the patient's humours (The Touchstone of Medicine, 1687).$^{3}$ Galen also taught that each disease was associated with a specific pulse and Floyer, in order to be able to count the pulse with precision, invented a special watch that ran for one minute (The Physician's Pulse Watch, vol 1, 1707). ${ }^{45}$ His interest in the pulse was stimulated also 
by the publication of Andreas Cleyer's Specimen medicinae Sinicae (1682), which brought the ancient Chinese pulse lore to the notice of the West. ${ }^{6}$

Floyer was a great enthusiast for cold bathing and built a cold bath for his patients in Lichfield (The History of Cold Bathing, 1697), but favoured especially the waters of Buxton and Matlock. His advocacy of cold bathing may have had religious overtones. He asserted that the Great Flood had purified the earth and he considered that complete immersion in baptism was beneficial. His faith in hydrotherapy came to be ridiculed and a contemporary diarist wrote of a deceased friend: "His death was chiefly owing to an infirmity caused by his throwing himself, about midnight in winter time, into the river, upon reading Sir John Floyer of Cold Baths."'

Floyer wrote his many books while living in Lichfield, where a local bookseller, Richard Johnson (who printed several of his books), consulted Floyer regarding his son Samuel, a sufferer from scrofula. On Floyer's advice, the lad was taken to London and "touched" by Queen Anne. The patient was, of course, the future great lexicographer, Doctor Samuel Johnson. ${ }^{8}$

From his youth Floyer suffered from asthma, which led him to make a special study of the condition (A Treatise of the Asthma, 1698). In his later years he developed an interest in the preservation of the health of the aged and he was the author of the first book on geriatrics, in which he observed that "Every man is a fool or becomes his own Physician at 40 or 50 years of age" (Medicina Gerocomica, 1724). Despite his asthma, Floyer's life was not shortened and he died in 1734 at the age of 85 .

\section{Floyer's "A Treatise of the Asthma"}

A Treatise of the Asthma was published in 1698 (fig 2) and later went into a second edition in 1710 and a third in 1726. A French translation appeared in 1761 and a German in 1782. Floyer dedicated the work to his friend and mentor Dr Phineas Fowke, FRCP (1638-1710), of Little Wyrly Hall, Staffordshire, who was physician to St Bartholomew's Hospital and to Charles II.

Addressing himself "To the Reader," Floyer commences with a description, along galenic lines, of the processes of normal respiration and then considers "the several Species of the Depravations of Our Respiration ....":

“(1) On The preternatural State of the Blood, and immediately on the preternatural Pulsation of the Right Ventricle of the Heart.

"(2) On The Obstruction of the Blood-Vessels or Air-Vessels; or else, their Compression, or Constriction.

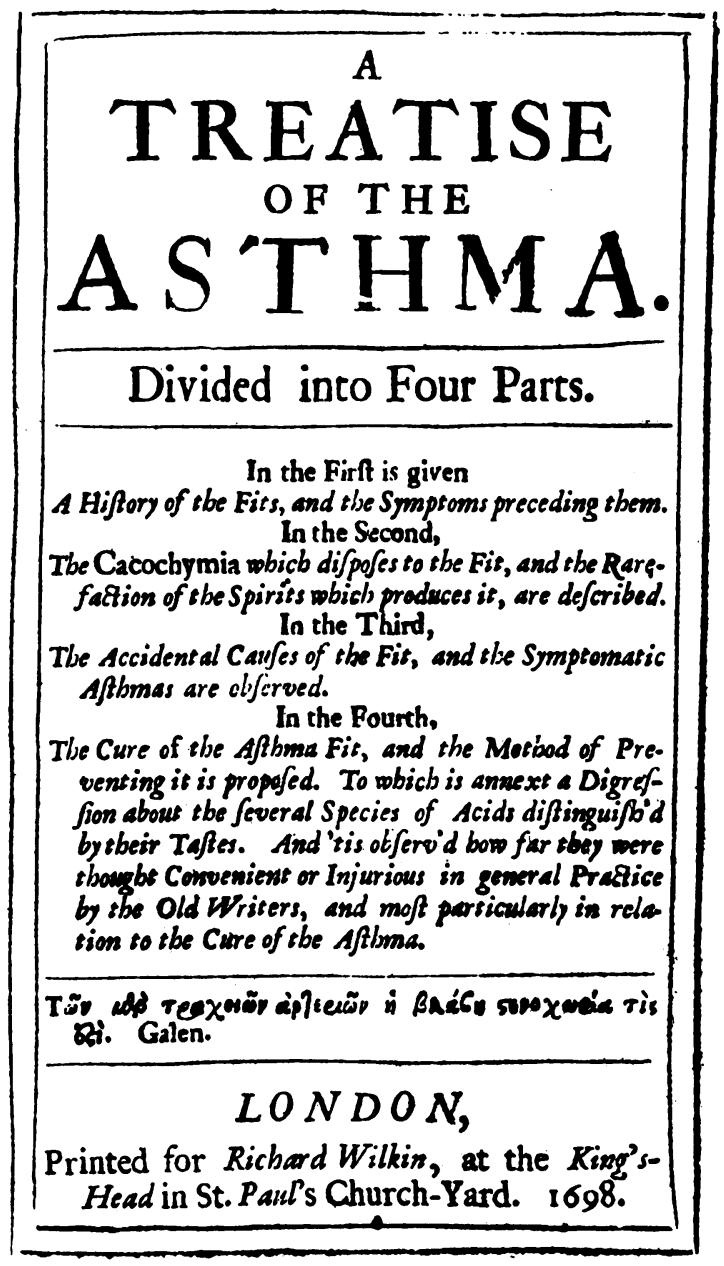

Fig 2 "A Treatise of the Asthma": first edition, 1698-title page. (By courtesy of the Wellcome Institute Library, London.)

"(3) On The Muscles designed in Respiration, to open and close the Breast; or else on the preternatural State of the Spirits, moving the Muscles."

Translated into modern terminology, this covers (1) right sided cardiac failure in pulmonary disease; (2) obstructive airways disease and asthma; and (3) the restrictive type of impairment of pulmonary function.

Floyer elaborates on (2), the obstructive dyspnoeas:

"When the Muscles labour much for Inspiration and Expiration thro' some Obstruction, or Compression of the Bronchia, etc. we properly call this a Difficulty of Breath: but if this Difficulty be by the Constriction of the Bronchia, 'tis properly the Periodic Asthma: And if 
the Constriction be great, it is with Wheezing; but if less, the Wheezing is not so evident."

Floyer then provides "A Scheme of the several Species of the Asthma: (1) The "Continued Asthma," comprising a variety of pulmonary conditions, associated with dyspnoea, which one would not now consider to be asthma-for example, "a dropsy of the Breast"; and (2) "Periodical or Flatulent Asthma," corresponding to what one would now regard as asthma.

Floyer refers to his own experience as a sufferer from asthma:

"My Design in this Treatise is to describe the Periodic Asthma, to which I have been long subject and that has given me many opportunities of considering the History of the Disease more nicely than it was possible for Physicians who have always an imperfect Account of Chronicall Cases from Patients; and to that I must impute their ill success in many Chronicall Diseases."

Floyer continues with this plea:

"I hope this Treatise will excite those Physicians who are subject to Chronicall Diseases to observe nicely the History of their Disease, and to describe all its sensible Phenomena.'

The Treatise (of 208 pages) is divided into four parts: (1) the asthmatic attack; (2) the nature of asthma; (3) the factors precipitating the asthmatic attacks; (4) the management of asthma, curative and preventive.

PART I: FLOYER ON THE ASTHMATIC ATTACK Floyer provides a masterly and graphic description of the asthmatic attack:

"The Lungs feel rigid, stiff or inflated ... the asthmatic seem to suck in their Breath, and wheeze a little towards Night: This Straitness of Breath, seems to be for want of an easie Inspiration; the Diaphragme cannot contract itself to move downwards, and that occasions a laborious Breathing to draw in Air; the Trachea or its Bronchia, have their Membranes and Nervous Fibres contracted, by which the Wheezing is made in Expiration. The Asthmatic seems to have a Convulsive Cough before the Fit, and sometimes a little slimy Phlegm is spit up; but both of them are very inconsiderable.

"At first waking, about one or two of the Clock in the Night, the Fit of the Asthma more evidently begins, the Breath is very slow; but after a little time, more strait; the Diaphragme seems stiff, and tied, or drawn up by the Mediastinum. It is not without much difficulty mov'd downwards; but for enlarging the Breast in Inspiration, the Intercostal Muscles, which serve for the raising of the Ribs, and lifting up the Breast, strive and labour more vehemently; and the Scapular and Lumbar Muscles, which serve for strong Inspiration, join all their Force, and strain themselves to lift up the Breast and Shoulders, for the enlarging the Cavity of the Breast, that the Lungs may have a Place sufficient for their Expansion, and the Air may more plentifully inspire.

"The Asthmatic is immediately necessitated to rise out of his Bed, and sit in an erect Posture, that the Weight of the Viscera may pull down the Diaphragme.

"The Muscles which serve for Expiration, cannot easily perform the Contraction of the Thorax, being hindered in that by the Stiffness or Inflation of the Membranes in the Thorax; for though the Asthmatic expire more easily than they can draw in their Breath, yet the Expiration is very slow, and leisurely, and Wheezing; and the Asthmatic can neither Cough, Sneeze, Spit, or Speak freely; and in the Asthmatic Fit, the Muscular Fibres of the Bronchia and Vesiculae of the Lungs are contracted and that produces the Wheezing Noise, which is most observable in Expiration ..."

Floyer again drew attention to the prolonged expiratory phase of respiration in asthma and emphysema in The Physician's Pulse Watch, vol 2 (1710), where in appendix III he writes of the pulse in asthma:

"There is this inequality between the Inspiration and Expiration in the Asthma, the Inspiration is made of the time of 3 pulses and the Expiration of 10 pulses."

\section{PART II: FLOYER ON THE NATURE OF ASTHMA}

Although Floyer's idea of the mechanism of the asthmatic attack as due to bronchospasm was a major breakthrough, his ideas regarding the underlying causes of the asthmatic state remained essentially galenic. He ascribes the "Periodic Asthma" to

"a flatulent slimy Caccochymia [dyspepsia] which is bred in the Stomach, and creates inflation there, and gives an Effervescence in the Blood and an Inflation in the Membranes of the Lungs."

He considers that at 2 am

"the Chyle is more plentiful in the blood... and the viscid Chyle and Lymph will not easily circulate through the lungs of asthmatics."

Vomiting, by "bringing up" the slimy phlegm, gives relief. Floyer also believes that an ephemera (febrile illness) may also trigger off an attack of asthma. He summarises the foregoing thus:

"The Asthma is a High, Slow, Rare and Laborious Respiration, which depends immediately on the inflation of the Membranes of the Lungs (which constringe the Bronchia, Bladders of the Lung and Blood Vessels) by Windy Spirits, rarefied or propelled through the Glands of the Brain, either by external Accidents or a periodic Febrile Effervescence of the Blood."

Floyer then draws an interesting analogy with 
priapism, which the ancients considered also to be due to "windy inflations":

"For as the Windy Spirits in the Sleep inflate the Membranes of the Penis, and by stopping the circulation of the Humours, make a Stiffness or Inflation: so it may be in the Nervous Fibres of the Lungs: there are no true Muscles in either Part to make this Inflation but only Nervous Fibres; and in the Muscular Membranes, the Stiffness of these Parts is not a Convulsion, for that is transient, but a true Inflation which may endure many Days ..."

\section{PART III: FLOYER ON FACTORS PRECIPITATING} THE ASTHMATIC ATTACK

Of his own asthma, Floyer had written in the Preface:

"I shall give the History of my Asthma ... I have for many years kept a Diary of that Disease, out of which I can give a more true Account than if I had now recollected what has long since passed";

and in Part I he continues:

"I cannot remember the first Occasion of my Asthma; but have been told that it was a cold when I first went to School. As my Asthma was not hereditary from my Ancestors; so, I thank God, neither of my two Sons are inclined to it, who are now past the Age in which it seized me. I at first was only troubled with it at the great Changes of the Year, and preserv' $\mathrm{d}$ my self tolerably in Health for some Years, by taking Purging Pills frequently; I never had any considerable Fit in Oxford for Twelve Years that I liv'd there, which I imputed to the Clearness of that Air, and the Spare Diet there; but as oft as I came into Staffordshire, into my Native Air, I was usually visited with a severe Fit or two. The Air of a Town makes the Fits more severe when they happen; but I do not think the Asthmatic so much expos'd to the Accidents of the Weather in a City, as in the Country; the Asthma being a Fever Fit, all hot Regimens and hot Air, such as that of a City, may dispose some lean hot Bodies to Coughs, and consequently Fits; but I could never observe my Fits to come oftener in London than in the Country, only I find them more severe in a close Air, as they would be in a close hot Room, when they happen."

The factors liable to precipitate an asthmatic attack are now discussed.

\section{The Air}

Floyer refers to the experiments of the Hon Robert Boyle (1627-1691) and considers that the barometric pressure influences asthma. He finds that dry air is good for the asthmatic and mist is bad, while rain has little effect. Asthmatic attacks, he says, tend to occur around the time of the full or half moon, because the weather is less stable at these times. "Damp Houses and fenny Countries" are bad; east winds are harmful and so is summer heat.
Cold, even frosty, weather is best. He writes:

"I observed that in the Winter were Sixteen Fits, but in the Summer Months, I had Twenty Fits ..."

Floyer also observes:

"The Fit of the Asthma is generally increased by the Heat of the Bed, and it usually seizes them there, and they are obliged to rise out of it, and they can bear a great degree of Cold, in sitting up all Night, the Windows open on them ...."

Any strong smells such as "Candles put out" or those associated with certain occupations (for example, soap making, wine fermenting, or work associated with fumes of metals such as quicksilver) are harmful. Of tobacco fumes, Floyer has this to say:

"During the Fit of the Asthma, the Smoak of Tobacco is so offensive that it very much straitens the Breath, if it be smoaked the first Day of the Fit, and much endangers a Suffocation. There are many Asthmatics that cannot bear the smell of it; therefore its Foetor is injurious any time, its Heat thickens the Phlegm and rarefies their aerial Spirits, making them restless; all the good it can do is to discuss the Windiness after the Fit abates, and to help the coughing up of Phlegm."

\section{Diet}

Floyer reports that food with "hot tastes" and items such as eggs, cheese, and oysters are harmful. He considers strong liquors harmful but approves of the moderate imbibing of mead.

\section{Exercise}

Floyer was aware of exercise induced asthma:

"All violent Exercise makes the Asthmatic to breathe short .... and if the Exercise be continued it occasions a Fit ...."

\section{"The Passions"}

Floyer quotes Hippocrates' aphorism "that Asthmatics should abstain from Anger and Shouting." $\mathrm{He}$ finds that "much Study... may occasion a Fit .. . because Study inflames the Spirits." Floyer was certainly aware of the importance of psychological factors and specifically referred to cases of "Hysterical Fits:"

"Hysterical women hold their breaths long through the Convulsion of the Muscles of the Belly during the Fit; and therefore may by stopping the Motion of the Breath, strain the Nerves and Membranes..."

\section{Excretions}

Floyer points out that "the Asthmatic always makes a great Quantity of pale Water in the Fit ..." and asserts that emetics and purges, if excessive, may 
bring on asthma.

Sleep

Floyer considers that the asthmatic fit may sometimes follow sleep and that therefore: "by late sitting up I have put by the Fit for a Night or two."

\section{PART IV: FLOYER ON THE CURE AND PREVENTION OF ASTHMA \\ In the preface Floyer had written:}

"I have suffered under the Tyranny of the Asthma at least Thirty Years: and therefore think myself to be fully informed in the History of that Disease, and since I have practised Physick, I have made many Trials for the Relieving and Preventing of the Fits and out of Compassion to those Miserable Patients, I design to relate what I have found useful both to myself and others ..."

Floyer was sceptical of the efficacy of virtually all the treatments then in vogue. He tried out all the medicines on himself and concluded that the ancient galenicals probably helped him more than the recently introduced "chymical" ones. His recommendations regarding cure and prevention may be summarised as follows:

\section{Curative measures}

(1) Regimen: Floyer recommends that the patient should be encouraged to get out of bed as soon as possible and should sit quietly, in a "clean Air," avoiding the fumes of a fire or tobacco.

(2) Diet: on the first day fasting is desirable and later one should eat sparingly (for example, toast and wine-and-water).

(3) Bleeding: this is to be performed in small quantities, but only in extreme cases.

(4) Blisters: these should be applied to the limbs and shoulders; but Floyer is not in favour of cupping glasses.

(5) Clysters: these are useful, but violent purging is to be avoided during the attack.

(6) Vomiting: Emetics or a feather in the throat promote expectoration of viscid sputum; Floyer's favourite medicine is Squills, either the Oxymel or the vinegar preparation.

(7) Opiates: in small doses these are useful for assisting sleep.

\section{Preventive measures}

(1) Diet: Floyer writes:

"The most simple Diet is of Flesh-Meat, boiled or roasted, once in a day, with good Bread well fermented and well baked, and the Bran not too much dressed out. ..."
Long, cool drinks are beneficial.

(2) Regimen: avoidance of extremes of climate and gentle exercise such as horse riding are recommended.

(3) Expectorants: regular gentle vomiting is indicated, Floyer's favourite prescription being Oxymel of Squills.

(4) Laxatives: Floyer advises clysters weekly and purging three times weekly. One preparation referred to is "The Decoction of a Cock in Broth with Senna and Pectorals."

(5) Febrifuges and Sudorifics: these help fevers accompanying asthma.

(6) Digestives: various medicines such as bitters help the accompanying flatulent dyspepsia.

(7) Diuretics: there are numerous prescriptions, including millipedes and woodlice. Although Floyer advocates cold bathing he is not impressed by the drinking of the spat waters such as those at Bath:

"I liked these Waters when I drank them no hotter than new Milk; they passed well but I found no benefit by 'em."

\section{(8) Mental attitudes: Floyer writes:}

"Sadness stops the Motion of Humours and makes them more viscid. 'Tis observed, that all Asthmatics, being angry or sad, do fall into Fits oftener than when they are cheerful."

\section{PROGNOSIS}

Of prognosis, Floyer writes:

"I have met with some Asthmatics who have been so for Fifty Years, as they informed me, and yet in tolerable Health without any considerable Decay of their Lungs, or Disability to perform their usual Employments; which I oft reflect on to encourage my Patients, and myself, who yet can study, walk, ride, and follow my Employment, eat, drink, and sleep, as well as ever I could; neither am I yet sensible of any Decay in my Lungs ... and I have observed very few to die of the Asthma Fit ...."

FLOYER'S DISSECTION OF A BROKEN WINDED MARE In an appendix to $A$ Treatise of the Asthma Floyer makes two further observations related to asthma.

The first consists of some "Observations ... about weighing of an Asthmatic after Sanc- 0 torius' manner, with an account of the Weight $\mathbb{D}$

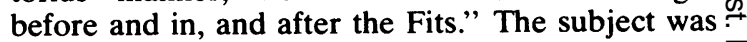
almost certainly Floyer himself, but the conclusions he draws from the experiments are equivocal, $\stackrel{\circ}{\mathbb{D}}$ although he makes an interesting comparison of the losses of weight from "insensible perspiration" in $\stackrel{\varnothing}{\varnothing}$ the warmer climate of Italy and the colder climate of Britain. 
The second part of the Appendix contains Floyer's description of a necropsy on a broken winded mare:
"In the Thorax, the Lungs appear' $d$ very much swelled or puffed up, and appear'd much bigger in the Broken-winded than usual; the Outside of the Lungs seem'd like Tubercula; but upon pressing I found those only Bladders very much distended with Air, as I found by cutting them. I blew up some Lobes of the Lungs and found the Air would not come out again, nor the Lungs subside of themselves; by which it was plain, that the Bladders of the Lungs had been extended or broken by some Strain in Running, and that the Air remaining either in the over-distended Bladders, or else passing thro' some Breach of them, betwixt the Fibrous Sub- stance of the Lungs; that caused a continual Inflation of the whole Lungs; which compressing the Bronchia and Blood-Vessels, produces a continual Dyspnoea, in which the external Air can't pass freely thro' the Trachea and its Branches in Inspiration or Expiration; and this difficulty occasions the great Labour and Nisus of the Respiratory Muscles.
" . . . the Bladders seem'd to make the Superficies of the Skin of the Lungs unequal, and the whole spungy Sub- stance of the Lungs seem'd swell'd with Wind: For no quantity of Humour appear'd anywhere. This Mare had not been Broken-winded above one Year. By this Observation it appears, that the Broken Wind depends on an Injury done to the Membranes rather than to the Humours of the Body."*

In a postscript Floyer reflects on these necropsy findings and considers that, while most cases of "periodic or flatulent asthma ... depend on rarefied serum in the nerves and fibres of the Membranes," some human cases could be associated with pulmonary changes similar to those found in the broken winded mare. Unfortunately he was not able to prove this because the "Resurrectionist" movement at that time objected to human necropsies, as he wrote in the letter to Dr John Thorpe (1710):

\footnotetext{
"If I could have procured the dissection of such Persons as have died of this Disease [asthma] in my neighbourhood, you should have had that evidence too; but my country-men are averse to such practises, though designed for their good. But I must leave this part of this Subject to the young Practitioners in London to look for the Air-Bladders in Asthmatics."*
}

The condition which Floyer described was, of course, pulmonary emphysema and was the first pathological account of the condition. ${ }^{9}$ Laennec (1781-1826) referred to this in his classic descrip-

*Floyer dealt with this subject again in a published letter dedicated to Dr John Thorpe, FRS (1682-1750), "A Letter concerning the Rupture in the Lungs, which is the cause of the Asthma in Mankind; and of Broken Winds in Horses, and of the Crocke in Hawks ..." (1710), in which he reported five further necropsies on broken winded mares. tion of the clinical and morbid anatomical features of emphysema. ${ }^{10}$

In the final section of the treatise Floyer also refers to the experiments of Richard Lower, FRCP (1631-91), who claimed that he "produced the Asthma in the Dog by cutting the Nerves of the Diaphragme." Floyer, however, rejects interference with phrenic nerve function as a cause of asthma in man.

\section{Discussion}

Sir John Floyer lived through an era of considerable upheaval in scientific and medical thought. Practising at the end of the 17 th century in a small town in the English Midlands, his original, innovative, and somewhat eccentric mind applied itself to many medical problems, but his own experience of asthma led him to make a careful study of this disease, enabling him to define the asthmatic state more accurately than any who had previously attempted this.

Asthma had been recognised from ancient times, but Hippocrates (460-370 BC), Aretaeus (81-138 AD), and Galen (139-199 AD) used the term asthma to describe any condition associated with dyspnoea. The great mediaeval physician Maimonides (1135-1204), in The Treatise of Asthma (1190)" also tended to confuse asthma with other pulmonary disorders. Nearer to the time of Floyer, Jean Baptiste van Helmont (1597-1644) and Thomas Willis (1621-1675) had distinguished asthma from the other varieties of dyspnoea, but they regarded the condition as a variety of nervous or convulsive fit, akin to epilepsy. The importance of Floyer's contribution was that, firstly, he defined asthma clearly, separating it from other pulmonary disorders; secondly, he considered that the cause of the dyspnoea was bronchial constriction, due to spasm; and, thirdly, he regarded the spasm to be tonic, more akin to catalepsy than to the clonic convulsion of epilepsy.

It is noteworthy that Floyer was able to achieve this merely by careful clinical observation alone, before the introduction of improved techniques of clinical examination of the chest such as percussion and auscultation. It must be admitted that Floyer's galenic ideas of pathogenesis and medicinal treatment do not stand up to modern inquiry; nevertheless, his treatise shows that he was familiar with the multifactorial basis of asthma-heredity, occupation, atmospheric pollution, hypersensitivity, infection, exercise, and psychological influences.

Floyer's teachings were to have a great influence on medical thought and practice during the following $\mathbf{1 0 0}$ years or more, both in Britain and abroad. 
Richard Mead (1673-1754) considered that Floyer had provided "a more particular history of the disease [asthma] than any other Author" (1762). ${ }^{12}$ The importance of Floyer's work was also appreciated by later writers on asthma, such as John Millar (1735$1805)$ in $1769,{ }^{13}$ Robert Bree (1759-1839) in $1797,,^{14}$ and Henry Salter (1823-71) in $1860 . .^{15}$

\section{Appendix: Floyer's major publications}

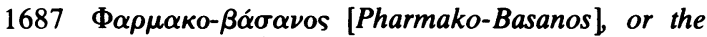
Touchstone of Medicine, discovering the Vertues of Vegetables, Minerals and Animals, by their Tastes and Smells. Vol 1. London: M Johnson.

1691 Vol 2

1696 The Preternatural State of the Animal Humours, described by their Sensible Qualities. London: M Johnson.

1697 An Enquiry into the Right Use and Abuses of the hot, cold, and temperate Baths of England. London: R Clavell. Republished later under other titles:

1702 The Ancient $\Psi v x \rho o \lambda o v \sigma i \alpha$ [Psychrolusia] Revived: or, An Essay to prove Cold Bathing safe and useful, in four Letters ... London: $\mathrm{S}$ Smith.

$1709 \Psi v \times \rho \circ \lambda o v \sigma i \alpha[$ Psychrolusia $]$ or, The History of Hot and Cold Bathing. London: B Walford.

1698 A Treatise of the Asthma. London: R Wilkin. Further editions in 1710,1717 , and 1726 published by $\mathbf{R}$ Wilkin and $W$ Innys.

1761 Traité de l'Asthma (French translation by MAF Jault). Paris: PF Didot jeune.

1782 Abhandlung von der Engbrüstigkeit (German translation by JCF Scherf). Leipzig: Dyk.

1699 A Relation of two Monstrous Pigs, with resemblance of Human Faces, and two young Turkeys joined by the Breast. Philosophical Transactions No $259 ; 21: 431$.

1702 Observations on the Class of Sweet Tastes, made by comparing the Tastes of Sweet Plants with Monsieur L'Emery's Chymical Analysis of them, in his Treatise. Philosophical Transactions No 279;23: 1160-72.

1707 A letter on bathing. In: Dr Joseph Browne: Account of Cures performed by Cold Baths. London.

1707 The Physician's Pulse Watch. Vol 1. London: S Smith and B Walford.

1710 Vol 2. London: J Nicholson, W Taylor, and $\mathrm{H} \mathrm{Cle-}$ ments.
1710 A Letter concerning the Rupture in the Lungs. London: $\mathrm{J}$ Nicholson and $\mathrm{H}$ Clements. [Also included in appendix to The Physician's pulse watch, Vol 2.]

1715 A Vindication of the Sibylline Oracles. London.

1717 Two Essays on the Creation and on the Mosaic System. Nottingham.

1718 The Sibylline Oracles, translated from Greek. London.

1719 An Exposition of the Revelations. London and $\vec{\circ}$ Lichfield.

1722 An Exposition and Vindication of Esdras. London.

1722 An Essay to Restore the Dipping of Infants in their Baptism. London.

1724 Medicina Gerocomica; or the Galenic Art of Preserving Old Men's Healths. London: F Isted.

1726 A Comment on Forty-Two Histories described by Hippocrates in his "Epidemics. ..." London: $\mathrm{F}$ i Isted.

\section{References}

${ }^{1}$ Dictionary of national biography.

${ }^{2}$ Townsend GL. Sir John Floyer (1649-1734) and his study of the pulse and respiration. J Hist Med $ळ$ 1967;22:286-316.

${ }^{3}$ Lindsay L. Sir John Floyer (1649-1734). Proc $R$ Soc Med 1951;44:43-8.

${ }^{4}$ Gibbs DD. Sir John Floyer MD (1649-1734). Br Med J 1969;i:242-5.

${ }^{5}$ Gibbs DD. The physician's pulse watch. Med Hist 1971;15:187-90.

- Cleyer A. Specimen medicinae Sinicae. 'Frankfurt: JP Zubrodt, 1682.

${ }^{7}$ Hearne's diaries. 1720: Bodleian Library, MS No 90:116.

${ }^{8}$ Gunn JA. Sir John Floyer (1649-1734). Medical Press and Circular 1934;189:297-9.

${ }^{9}$ Townsend GL. Sir John Floyer (1649-1734) and the discovery of pulmonary emphysema. Mayo Clin Proc 1969;44:484-8.

${ }^{10}$ Laennec RTH. De l'auscultation médiate. Vol 1. Paris: JA Brosson and JS Chaudé, 1819:225.

"Sakula A. Moses Maimonides' treatise on asthma. O Thorax 1981;36:560.

12 Mead R. The medical works. London: C Hitch,음 1762:186.

${ }^{13}$ Millar J. Observations on the asthma and on the houping cough. London: T Cadel, 1769.

14 Bree R. A Practical Enquiry into Disordered Respiration, $N$ distinguishing the Species of Convulsive Asthma. Their Cause and Indication of Cure. London: R Phillips, 1797.

${ }^{15}$ Salter H. On asthma: its pathology and treatment. London: John Churchill, 1860. 